The Version of Record of this manuscript has been published and is available in LANGUAGE AND INTERCULTURAL COMMUNICATION, 2017

http://www.tandfonline.com/doi/full/10.1080/14708477.2017.1368149

\title{
Towards a repertoire-building approach: multilingualism in language classes for refugees in Luxembourg
}

\begin{abstract}
This contribution examines how the diverse language resources that teachers and learners bring to the classroom can support the process of language learning. It draws on a range of linguistic ethnographic data collected at a French language course that was attended mostly by Syrian and Iraqi refugees in Luxembourg. Drawing on the analysis of multilingual interactional practices, the article sheds light on some of the opportunities for learning that emerged as a result of translation, translanguaging and receptive multilingualism. It discusses the relevance of these practices for building a repertoire of resources that enables forced migrants to communicate in multilingual contexts such as Luxembourg.
\end{abstract}

Keywords: forced migration, multilingualism in Luxembourg, repertoire building, translanguaging, translation, receptive multilingualism

Abstrait : Cet article examine comment les différentes ressources linguistiques que les enseignants et les apprenants apportent dans la classe peuvent promouvoir le processus d'apprentissage d'une langue. Les analyses s'appuient sur un ensemble de données ethnolinguistiques recueillies pendant des leçons de français auxquels ont participé des réfugiés syriens et irakiens à Luxembourg. En analysant leurs pratiques interactionnelles plurilingues, cet article signale les possibilités didactiques favorisées par les pratiques de traduction, translanguaging et le plurilinguisme réceptif. I/ aborde l'importance de ces pratiques pour l'élaboration d'un répertoire de ressources permettant aux réfugiés de communiquer dans un contexte plurilingue comme le Luxembourg.

Mots-clés : migration forcée, multilinguisme au Luxembourg, élaboration du répertoire, translanguaging, traduction, plurilinguisme réceptif

\section{Introduction}

Contemporary language education schemes for refugees and migrants are dominated by monolingual instructional practices that are inconsistent with current understandings both of how people learn (Cummins, 2007; García, 2009; Creese \& Blackledge, 2010; Le Nevez, Hélot \& Ehrhart, 2010) and of the functioning of the multilingual mind (Jessner, 2006; Cook, 2007; Canagarajah \& Wurr, 2011). Despite the pressing need for education initiatives in support of refugee integration, relatively little research has been conducted on language learning in contexts of forced migration, and even less in circumstances where multiple languages are at use. This article seeks to fill this gap by presenting a case study from Luxembourg. Drawing on 
The Version of Record of this manuscript has been published and is available in LANGUAGE AND INTERCULTURAL COMMUNICATION, 2017

$\mathrm{http} / / / w w w . t a n d f o n l i n e . c o m / d o i / f u l l / 10.1080 / 14708477.2017 .1368149$

a range of linguistic ethnographic data collected at a French course for refugees, it shows how the diverse language resources that teachers and learners bring to the classroom support the process of language learning. By studying how individuals build on the codes and resources accessible to them, it aims to contribute to current theoretical discussions on the affordances of multilingual pedagogies in contexts of migration and refuge. Providing empirical data on the use of translation, translanguaging and receptive multilingualism, the article discusses the relevance of these practices for language learning, especially in societies that are structured around highly diverse flows of people. It is hoped that the findings from this research will stimulate the debate about repertoire building and the need to align migrants' resources to their locally situated educational needs.

\section{Migration and multilingualism in Luxembourg}

The Grand Duchy of Luxembourg is a country of immigration. Almost two thirds of its population have a direct or indirect migration background, and cross-border workers account for almost half of the entire workforce (Statec, 2016a). Increased immigration movements are mainly attributable to Luxembourg's substantial economic success over the past few decades. As a result, the Grand Duchy is arguably one of the most multilingual countries in the world. Situated on the Romance-Germanic language border, Luxembourg has a long-standing tradition of multilingualism, which was acknowledged in the language law of 1984. According to the provisions of this law, Luxembourgish is the national language, French the language of the law, and Luxembourgish, German and French are all acknowledged as languages of administration. Hence, multilingualism in Luxembourg is not territory-based but is reflected in different patterns of language use. This distinguishes the Grand Duchy from other multilingual countries in Europe, such as Belgium or Switzerland, where language legislation is governed by geographic distribution.

The above-described triglossic language situation has been substantially reshaped by increased migration movements since the 1950s, mainly from Portugal, Italy, the Balkan States and the Cape Verde Islands. Local multilingualism has been further enriched by the languages of other foreign nationals residing in the Grand Duchy. According to the national office of statistics (Statec, 2016b), the country now counts more than 170 different nationalities, including Syrians and Iraqis who, fleeing war and political unrest, have applied for asylum in Luxembourg [1].

Against this backdrop, Luxembourg constitutes an intriguing research setting for exploring the possibilities and complexities inherent to the process of language learning in multilingual societies. In fact, no Luxembourger is believed to be monolingual: moving fluidly 
The Version of Record of this manuscript has been published and is available in LANGUAGE AND INTERCULTURAL COMMUNICATION, 2017

$\mathrm{http} / / / w w w . t a n d f o n l i n e . c o m / d o i / f u l l / 10.1080 / 14708477.2017 .1368149$

back and forth between a multitude of languages is a communication method in its own right and members of the local society are believed to excel in it. Official government policies in Luxembourg continually draw upon the rhetoric of multilingualism to support claims about the country's openness and multicultural spirit. This (self-ascribed) openness, along with the legal recognition of three languages - Luxembourgish, German and French - is expected to facilitate the integration of foreign nationals. Nonetheless, this situation might appear puzzling to new arrivals from regions characterised by a 'monolingual habitus' (Gogolin, 1997) and a rather limited presence of Luxembourg's main languages. Mannan, a refugee from Aleppo (Syria) who sought international protection in Luxembourg, described his situation as difficult and unsettled:

It's difficult to live here. We have three languages, three new languages. It's difficult to learn three languages at once. Because of that I learn French right now. The rest I don't know.

Mannan's uncertainty is understandable in light of present-day language ideological debates. In general, new arrivals are strongly advised to enrol in French classes, as it is believed to improve their employability chances. Mannan recounts this expectation:

It wasn't my choice, but everybody here says you must learn French if you want work, if you want to study, if you want to do anything, you must learn French.

At the same time, ideologies situating Luxembourgish in the position of the 'sole language of integration' are gaining more prominence. Needless to say, Luxembourgish is the language resource new arrivals are least likely to have in their communicative repertoires. In this respect, Horner and Weber (2008) discuss the coexistence of nationalist and trilingual language ideologies. The conflicting nature of these ideologies gives rise to ambivalent messages as to what languages and what identities should be offered to newcomers. As a result, new arrivals such as Mannan often set ambitious language learning goals to fit into the traditional trilingual paradigm:

Yes of course, I'm interested [in learning other languages] but I can't because I need to learn French, after that I want to learn Luxembourgish, and after that German. There is no place for Portuguese or Italian.

Mannan's point of view gives a somehow ambiguous status to language resources outside the recognised trilingual model, such as Portuguese or Italian. This is perhaps not surprising in view of the mainstream media discourses around language, nationality and integration, which imply that societal multilingualism is problematic, especially when it breaks away from the prescribed trilingual-plus-English paradigm (Horner \& Weber, 2008; Horner, 2015). Yet, 
The Version of Record of this manuscript has been published and is available in LANGUAGE AND INTERCULTURAL COMMUNICATION, 2017

$\mathrm{http} / / / w w w . t a n d f o n l i n e . c o m / d o i / f u l l / 10.1080 / 14708477.2017 .1368149$

multilingual practices are widespread and attitudes towards multilinguals are rather favourable as demonstrated by previous research (Franziskus \& Gilles, 2012; de Bres, 2014).

The specific features of Luxembourg's language situation seemingly create favourable conditions for multilingual pedagogies. Relatively little research has been conducted on language education initiatives in support of the integration of forced migrants, and even less in circumstances as diverse as Luxembourg offers. In view of this, the article explores how teachers and learners embrace multilingual affordances in the context of a French language course for refugees. The theoretical framework for the analysis and the methodological complexities that emerged during the research are explained in the following section.

\section{Language learning in contexts of forced migration: theoretical considerations}

The dominant discourse in most EU countries underlines the idea that it is immigrants' duty to learn the respective national languages, for integration's sake (Van Avermaet, 2009). Luxembourg is no exception. For new arrivals, the acquisition of local languages is undoubtedly a form of personal enrichment. In circumstances of forced migration, however, to talk of traditional second or foreign language learning would be grossly misleading. Refugees do not acquire the languages of the mainstream society for the mere reason of approximating native speakers' performances. Languages form part of their everyday lived experiences and a failure to adapt to the new language situation can cause alienation in terms of identity. Owing to the rupture with the country of origin, feelings of linguistic insecurity are often highly salient.

In line with the argumentation put forward by Blommaert and Backus (2011), forced migrants' repertoires are seen as inventories of resources that have been accumulated in order to operate within the norms and expectations that govern social life. As the Luxembourgish example well illustrates, multilingual modes of communication can be part of these norms. Whenever new language resources are acquired, this changes the balance of the individual's communicative repertoire (Rymes, 2014). More specifically, García (2009) writes of recursive language acquisition, where the language learnt at a later stage shapes the competence of the language acquired earlier, and both mutually influence each other to move in new directions. Although the concept was introduced primarily to explain bilingual education, it equally applies to multilingual environments.

Upon arrival, refugees are offered language education schemes, the primary aim of which is to promote the dominant languages of the receiving society. Meanwhile, their complex repertoires consisting of other language resources are often neglected. In our view, this line of action does not acknowledge the complexity of language learning in societies where multiple languages are at use on a daily basis. This raises crucial questions: What 
The Version of Record of this manuscript has been published and is available in LANGUAGE AND INTERCULTURAL COMMUNICATION, 2017

http://www.tandfonline.com/doi/full/10.1080/14708477.2017.1368149

happens if the multilingual realities of teachers and learners are introduced to the classroom?

How can their diverse language resources support the process of learning? This article seeks to answer these and similar questions.

As argued by Canagarajah and Wurr (2011), multilinguals bring to the language classroom resources and strengths that monolinguals may not possess. They maintain that it is not a shared grammar that enables communication, but communicative practices and strategies that are used to negotiate language differences: 'these strategies are not a form of knowledge or cognitive competence, but a form of resourcefulness that speakers employ in the unpredictable communicative situations they encounter' (Canagarajah \& Wurr, 2011, p. 2). From this perspective, multilingual orientation to language acquisition is intertwined with repertoire building. Rather than aiming for total competence in individual languages, multilinguals prefer developing a range of codes for a range of purposes.

Out of the numerous multilingual practices used by refugees, this article focuses on translation, translanguaging and receptive multilingualism, as these have been the most salient features in our research context. The use of learners' first languages has been a point of contention in foreign language education. As summarised by Carreres (2006), proponents of audiolingual and communicative methods consider the use of the mother tongue counterproductive in the process of acquiring a new language. It is believed to hold learners back from taking the leap to express themselves in the target language. This situation is assumed to be further complicated by the introduction of additional language resources that operate as the bridging language between teachers and learners with differing mother tongues. Some recent thinking on language learning (Byram \& Hu, 2013), however, stresses the potential of translation as a language teaching tool and calls for a reassessment of its role in language pedagogy. While much valuable work has been done in recent years (Calis \& Dikilitas, 2012), we still lack a strong empirical foundation for using translation as an effective pedagogical tool. The ways in which informal translations can become a form of peer support are of special relevance for this research.

The second multilingual practice examined here is translanguaging (García, 2009; Creese \& Blackledge, 2010). In accordance with García and Li Wei (2014), translanguaging is understood as a dynamic meaning-making process whereby multilingual speakers go beyond the conventional division between languages and modalities. For García (2009) a translanguaging approach to teaching and learning has the potential to liberate the voices of language-minoritised learners. Alongside 'translanguaging', a number of other terms have been coined to describe emerging multilingual practices, such as 'polylingualism' (Jørgensen, 2008), 'metrolingualism' (Otsuji \& Pennycook, 2010) and 'heteroglossia' (Bailey, 2007). We 
The Version of Record of this manuscript has been published and is available in LANGUAGE AND INTERCULTURAL COMMUNICATION, 2017

$\mathrm{http} / /$ www.tandfonline.com/doi/full/10.1080/14708477.2017.1368149

have opted for 'translanguaging' as it is the most widely used concept in theoretical discussions surrounding education. However, we are very aware of the extra layers and dimensions of the other terms listed above. Hence, our analysis also draws on Otsuji and Pennycook's understanding of fluid linguistic identities and Jørgensen's definition of polylingualism as well:

Language users employ whatever linguistic features are at their disposal to achieve their communicative aims as best they can, regardless of how well they know the involved languages; this entails that the language users may know - and use - the fact that some of the features are perceived by some speakers as not belonging together. (Jørgensen, Karrebæk, Madsen \& Moller, 2011, p. 34)

Such an analytic gaze enables a better understanding of how people select different resources and what motivates their choices. This approach brings several advantages as it conceptualises multilingual speech events as a response to precise, locally situated communicative needs (Lüdi, 2006). The term resources itself presupposes the existence of an active subject who has amassed a repertoire of resources and who activates this repertoire, combining its diverse elements according to his/her needs, knowledge and whims (Lüdi \& Py, 2009).

The third strategy that allows multilingual language users to accomplish their communicative tasks is receptive multilingualism. A growing number of studies suggest that receptive multilingualism is not limited to typologically close languages. On the contrary, it has been documented in contexts of migration and between speakers of different language families (Rehbein, ten Thije \& Verschik, 2011; Franziskus \& Gilles, 2012). Some research suggests that it can also serve as a starting point for language learning (Vetter, 2011). This article will focus on highly complex cases of receptive multilingualism where interactants have very few resources in each other's languages.

\section{Multilingual classroom ethnography}

The data presented in this article were collected in an ongoing doctoral research project [2]. Based on linguistic ethnographies undertaken in various settings of language learning and socialisation, the PhD project studies the linguistic integration trajectory of Syrian and Iraqi refugees who have sought international protection in Luxembourg. All research activities were approved by the Ethics Review Panel of the University of Luxembourg and the National Commission for Data Protection of the Grand Duchy of Luxembourg. Informed consent was obtained from each project participant. The informed consent documents along with a general outline of the project were made accessible to the participants in both English and Modern Standard Arabic. 
The Version of Record of this manuscript has been published and is available in LANGUAGE AND INTERCULTURAL COMMUNICATION, 2017

$\mathrm{http} / /$ www.tandfonline.com/doi/full/10.1080/14708477.2017.1368149

Operating as a researcher in this multilingual context has been extremely challenging.

The researcher's first language is Hungarian, but she has previously relied mostly on other languages, including Slovak, English and Spanish, for study, work and research. Of the languages relevant for this project, she has knowledge of English and French. She started learning French prior to her arrival in Luxembourg in 2014. Being a French language learner while researching in French has caused some additional difficulties, particularly with regard to data collection and analysis. To ensure the correct representation of the findings, all excerpts presented in this article have been validated by language experts with background in French studies. The researcher has also collaborated with two native speakers of Arabic: Malika, a lecturer in TESOL who has a Master's degree in translation, and Yacine, a graduate student of the University of Luxembourg's Master's programme in Learning and Communication in Multilingual and Multicultural Contexts. Asked about their linguistic resources, they described themselves as speakers of Jordanian and Moroccan Arabic, respectively. Both confirmed that they understand most of the other dialects as well. As to the project, they have been involved in the interviewing process, translation of the informed consent documents, and the transcription, analysis and translation of audio-recorded interactions. During the fieldwork, the researcher often relied on approximate translations offered by the research participants.

This contribution focuses on preliminary findings from a French language course for beginners. The course has been running since February 2016 with sessions of approximately 90 minutes held twice a week. It is taught by volunteers in a community centre affiliated with a local church situated in a residential area of Luxembourg City. The course relies on materials compiled by the centre's teachers and aims to provide elementary language knowledge in French, equivalent to the CEFR A1 level [3]. After initial interviews with the course coordinator and various collaborators, the researcher visited two sessions at the beginning of the course in February, three sessions in May, two sessions in November 2016 and two sessions in the first quarter of 2017. It should be noted that our conceptualisation of the research context goes beyond the narrow confines of the classroom as a teaching-learning environment with strict spatial and temporal boundaries. The volunteers and asylum applicants - perhaps inadvertently and out of necessity - created an open and dynamic learning space where structured language learning tasks are carried out parallel to and as part of social interaction, meeting and exchanging, community work and educational counselling. Most of the data analysed here stem from audio-taped interactions recorded by the researcher in this complex learning environment, which will be referred to as 'the classroom' hereafter.

In line with the principles of linguistic ethnography (Copland \& Creese, 2015), these interactional data were complemented by ethnographic fieldwork, including participant 
The Version of Record of this manuscript has been published and is available in LANGUAGE AND INTERCULTURAL COMMUNICATION, 2017

http://www.tandfonline.com/doi/full/10.1080/14708477.2017.1368149

observation and biographical interviews with both language teachers and asylum applicants.

Of the three teachers who have been running the classes, two agreed to participate in the study: Marie, a French national and language teacher by education who has a part-time job in a French school in Luxembourg City, and Marianne, a British citizen and French-English bilingual who has lived in Luxembourg for the last 10 years. Furthermore, the data featured in this article come from three other research participants: Patrick, an Iraqi engineer who has sought asylum in Luxemburg in August 2015, as well as Mannan and Ram, who arrived at the Grand Duchy from Syria at approximately the same time [4]. The research participants were selected through convenience sampling. Although comparability was not sought, the participants reflect some of the diversity of linguistic profiles, educational backgrounds and migration experiences that refugees have recently brought to Luxembourg [5].

One formal interview and various informal interviews were undertaken with each research participant using both open-ended and targeted questions. The participants were given the choice of doing the interview in English or in their language of preference with interpretation [6]. The purpose of the interviews was to gain a nuanced understanding of the research context and capture the participants' unique perspectives on linguistic integration in Luxembourg. In writing this article, the focus was first and foremost on narratives of classroom experiences along with the language resources the participants reported to have at their disposal. The information of interest was extracted using content analysis. In line with Patton's definition (2002), the analytical process consisted of a sense-making effort to identify core consistencies and meanings. The insights thus obtained proved to be a valuable source of information for the contextualisation of the audio-recorded classroom exchanges discussed below.

Participants were audio-recorded during their usual classroom activities. We used digital recording devices (a notebook and a smartphone) that were placed unobtrusively but close to the research participants, recording from the moment of their arrival at the centre until their departure. Following an initial analysis, selected fragments were transcribed and analysed using interactional sociolinguistics, a discourse-analytical framework proposed by Gumperz (2003). It combines ethnographic and contextual information with detailed turn-byturn analysis of communicative exchanges in order to understand what participants intend to convey. Our analysis attempts neither to determine the number of languages involved, nor to categorise the elements as strictly belonging to one or the other language. Nevertheless, to adequately illustrate how research participants draw upon their resources, we do indicate in the extracts below whether and how the different items are associated with one or more languages [7]. The languages are marked as follows: French is in regular font, English in bold, 
The Version of Record of this manuscript has been published and is available in LANGUAGE AND INTERCULTURAL COMMUNICATION, 2017

$\mathrm{http} / / / w w w . t a n d f o n l i n e . c o m / d o i / f u l l / 10.1080 / 14708477.2017 .1368149$

Portuguese underlined, German in bolded italics and Arabic is written in Arabic script [8]. English translations are provided in italics. Explanatory comments are indicated in curly brackets. The transcription conventions for the extracts can be found in the Appendix.

\section{How to build on multilingual repertoires?}

This analytical section explores some of the multilingual interactional practices that teachers and learners engaged in to make themselves understood and achieve their language learning goals. The recordings and ethnographic observations showed that French, English and Arabic were the most commonly used language resources in the classroom [9]. French, apart from being the target language of the course, appeared to be a valuable communicative resource in the meaning-making process, as shown in the excerpts below. During the initial sessions observed in February 2016, the two language teachers, Marie and Marianne, followed different pedagogical strategies for supporting language learning in this multilingual environment. In her effort to provide maximum linguistic input, Marie insisted that both teachers speak preferably French only, while Marianne saw the use of English as an absolute necessity at the beginning. An explanation for this discrepancy between their views on how to approach a multilingual classroom could be found in their different professional trajectories and ideologies about language teaching. Talking about her experience, Marianne also noted the difference and explained the initial classroom practices as follows:

At the beginning it was good with my English, it really really helped, that I was here, because Marie didn't want to speak English. [...] And the vernacular language still has to be English. But otherwise, when they are more often here, we do much less English now. We are trying to do everything in French.

The positioning of English as vernacular language is not unusual in contexts of $L 2$ teaching for immigrants, particularly in Luxembourg. In our view, the strategy of translating into English worked well with some learners, but proved to be insufficient with others. Although both teachers confirmed that most if not all learners within the group had 'some knowledge' of English - accumulated through formal schooling and/or informal channels of learning - the resources they had were not in all instances suitable for metalinguistic reflection or the clarification of exact meanings. For some learners, the contents and explanations were more accessible in French, despite limitations of the A1 level, arguably due to the language exposure they had experienced since arriving in Luxembourg and/or their unique language biographies. For instance, in his learning process, Ram often referred to Portuguese expressions he had learned from his new neighbours in Luxembourg, who happened to be Lusophones. Interestingly, part of the group saw Marianne's presence as an opportunity to improve their 
The Version of Record of this manuscript has been published and is available in LANGUAGE AND INTERCULTURAL COMMUNICATION, 2017

http://www.tandfonline.com/doi/full/10.1080/14708477.2017.1368149

English: parallel to their learning tasks in French, these learners often discussed with her questions and concerns related to English vocabulary as well.

Given that most of the group came from Arabic-speaking countries, the presence of Arabic at each step of the learning process was no surprise. Except for the asylum applicants from the Balkans, Arabic was either the learners' mother tongue or the language of their formal schooling. This explains why the overwhelming part of exchanges between the learners occurred in this language, including metalinguistic reflections, translations, discussions of how to accomplish the tasks and conversations beyond the course contents. It was mainly the more advanced learners, particularly the learners fluent in English, who assumed the role of mediators, providing translation, explanation or clarification where needed. According to Ram, whenever a concept was not understood in French, the group 'pushed the teacher to say it in English', and those who then managed to grasp its meaning translated it to Arabic, which made the 'process of learning much more fluid and much more comfortable'.

As to the teachers, neither Marie nor Marianne reported any knowledge of Arabic besides some well-known words and phrases. Nevertheless, a closer look at the data revealed several instances in which Marie did have adequate resources and receptive competence to follow the negotiation of meanings in Arabic and confirm the correctness of the translation agreed on between the learners. When asked about this, Marie explained that she had formerly worked in the suburban areas of Lille and Paris, teaching mostly pupils from North Africa. She also remembered some words and expressions from her travels to Syria, Jordan and Lebanon. This example echoes Blommaert and Backus' (2011) view on repertoires: different learning modes, including brief or informal encounters with languages, lead to different degrees of knowledge. As Marie's case well illustrates, even very limited resources have their place, function and above all potential within a speaker's repertoire.

It is worth mentioning that the comparison of data collected throughout the course revealed some changes in the patterns of interaction over time. At the beginning, the teachers' choices were limited to the use of French and/or French-English translations (sporadically), whilst the learners' linguistic and cultural resources were introduced gradually to the classroom. An increasingly better understanding of the asylum seekers' background enabled Marie and Marianne to adopt a more personalised approach that took account of each learner's language biography and built on his/her resources. The class environment thus became more communication-friendly, as illustrated by the examples below.

In working with Mannan and the other learners who had a good (receptive) command of English, French-English translation was an efficient strategy to achieve shared understanding. In contrast, the asylum applicants who showed more advanced knowledge of 
The Version of Record of this manuscript has been published and is available in LANGUAGE AND INTERCULTURAL COMMUNICATION, 2017

$\mathrm{http} / / / w w w . t a n d f o n l i n e . c o m / d o i / f u l l / 10.1080 / 14708477.2017 .1368149$

the course contents preferred reformulations and paraphrasing in French. Learners who claimed to have no knowledge of English except for a few words and set expressions, as did Ram, for example, relied strongly on explanations provided by their peers in Arabic. Those members of the group who had strong receptive competences in French and/or English were usually the ones assuming the role of mediators between the teachers and the rest of the group. In our observations, these learners felt more empowered and confident in other situations of language learning as well: for example, Patrick was described by his German teacher as having very good command of both English and French. Establishing comparisons between French and the learners' mother tongue/other languages in their repertoires further exemplifies the plethora of resources present in the classroom. Learners and teachers searched regularly for similarities and differences between the different language codes in order to enhance the learning process. The extract below illustrates how Marie (Mar), Ram (Ra) and Mannan (Man) negotiated the meaning of the French adjective 'humide' using its English equivalent:

Extract 1: 'La même chose in English'

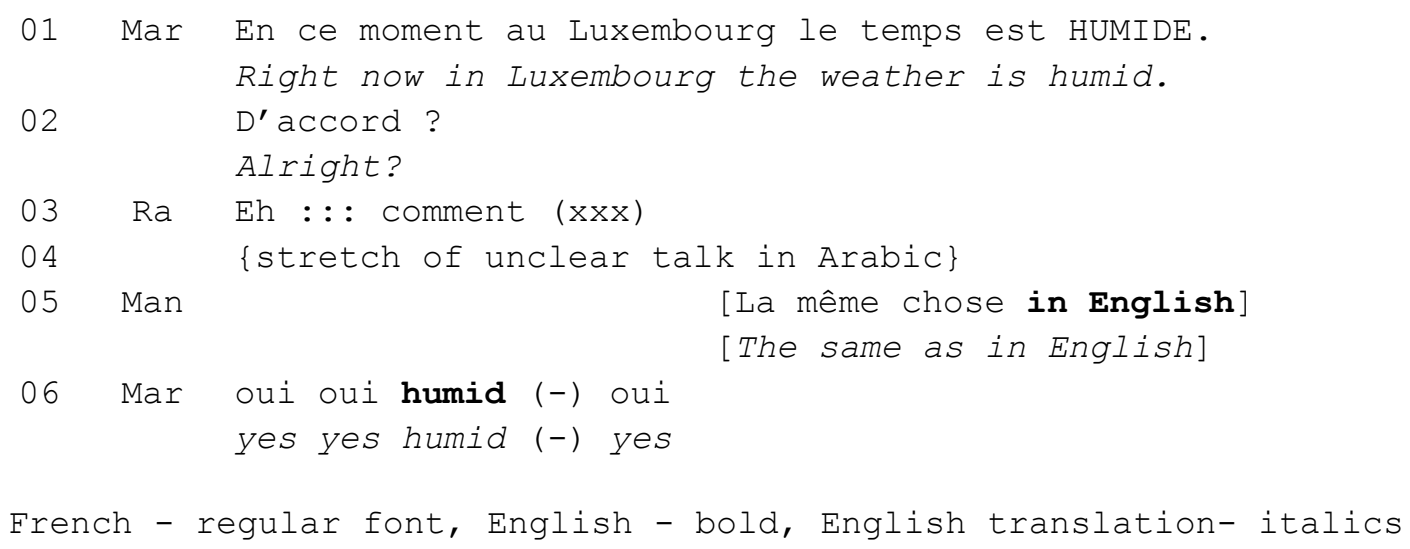

The use of the various language resources within the classroom was not as structured as it might appear. For instance, French words and expressions emerged in all interactions, regardless of whether the majority of the communication was taking place in English, Arabic or other languages. This was mainly due to the nature of the activities observed, that is, accomplishment of tasks aimed at the development of spoken and written skills in French. In the following example, Marianne (Ma) was helping an asylum applicant from Syria ( $\mathrm{Aa}$ ) to complete an exercise in writing. The task was to transform the example sentences into questions.

Extract 2: 'So the question is'

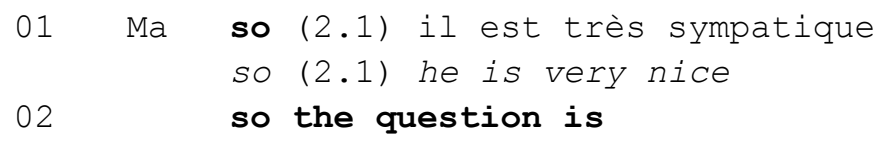


The Version of Record of this manuscript has been published and is available in LANGUAGE AND INTERCULTURAL COMMUNICATION, 2017

http://www.tandfonline.com/doi/full/10.1080/14708477.2017.1368149

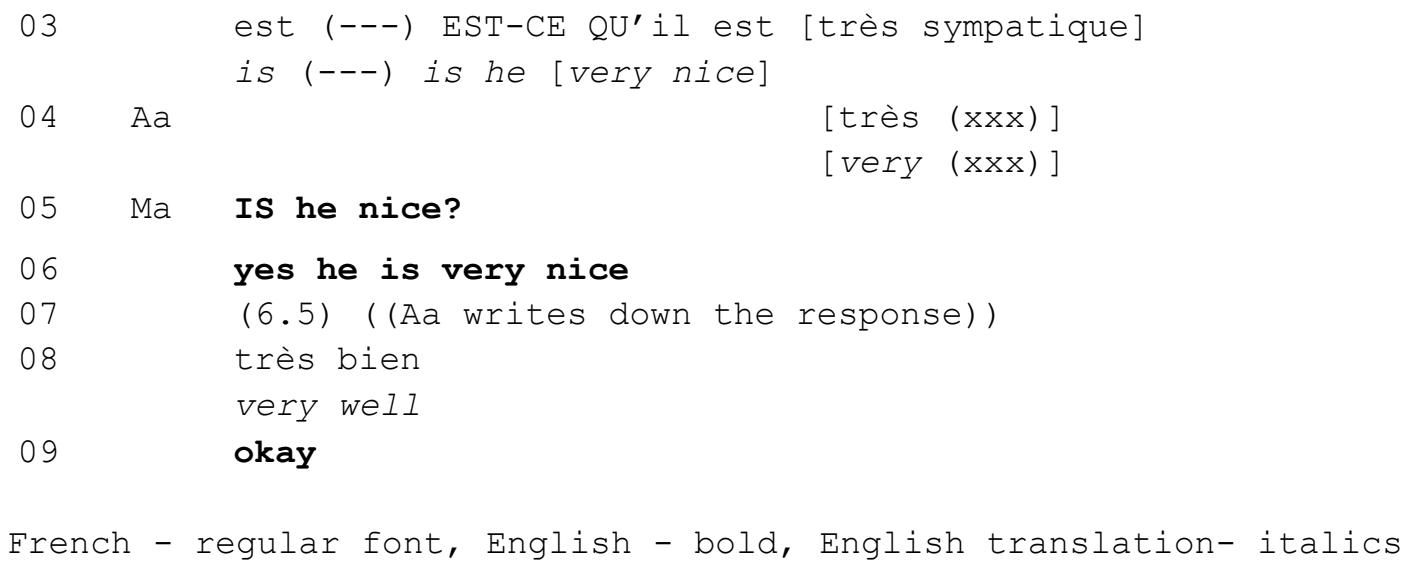

In this short sequence, Marianne clearly uses English to communicate with the learner and switches to French only when reading the example sentence (line 1) and giving the correct solution (line 3). Afterwards, she continues in English, offering a translation of the phrases that appeared in the exercise. Although similar exchanges show some features of translanguaging practices, we do not necessarily analyse them as such. French lexical items here seem to serve as keywords borrowed from the linguistic input teachers and learners work with. Similar items do not form part of the learners' 'inventory' of resources, they are not yet entrenched in their minds.

These interactional mechanisms differ, in our view, from the extracts presented below, which are considered to be examples of the flexible (re)combination of resources in the speakers' communicative repertoires. These extracts form part of a sequence recorded during a session in May 2016. The three research participants involved in the interaction were Marianne, Patrick and Ram. As explained earlier, the interactional mechanisms are analysed bearing in mind the overall interview data and the contextual clues from the researcher's field notes. In the first extract below, Patrick ( $\mathrm{Pa}$ ) approaches Marianne (Ma) to seek her advice on how to engage in small talk with the security guard at the refugee home he lives in. He introduces the topic by enacting the situation: he impersonates the guard who usually greets him with a 'How are you today?' in French.

Extract 3: 'Comment allez-vous ?'

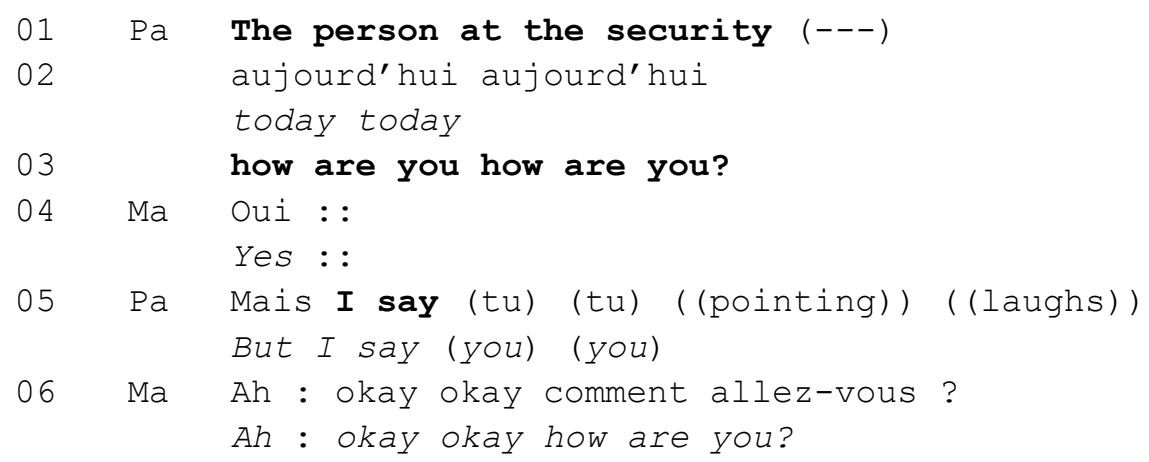


The Version of Record of this manuscript has been published and is available in LANGUAGE AND INTERCULTURAL COMMUNICATION, 2017

http://www.tandfonline.com/doi/full/10.1080/14708477.2017.1368149

07

08

09

10

11

$\mathrm{Pa}$

$12 \mathrm{Ma}$

$\mathrm{d}^{\prime}$ accord d'accord (2.3)

alright alright

Bon (-) alors (---) le plus facile tu peux dire

Well the easiest thing you can say is

Je ne comprends pas

I do not understand

Mais il ne faut pas dire Je ne pas bien.

But you shouldn't say not well

Pas compris.

Not understood.

Je n'ai pas compris, je ne $t^{\prime}$ ai pas compris.

I didn't understand, I didn't understand you.

French - regular font, English - bold, English translation - italics

To formulate his request, Patrick uses words that are conventionally labelled as English (lines 1 and 3) and French (line 2); however, in his utterances, he makes fluid shifts between these resources. Marianne's responses signal understanding (oui, okay, d'accord), which confirms that the way Patrick structures the information makes complete sense under the specific circumstances in which the interaction unfolds. It can be argued that the multilingual mode we observe here is an effective response to Patrick's locally situated communicative needs. Obviously, Patrick's gestures, mimic and movements are also important elements of the meaning-making process, suggesting that a range of verbal and non-verbal resources from his communicative repertoire is being deployed.

It must be noted that Patrick is one of the research participants who has a very good command of English. As most of the interactions between him and the researcher (including the initial interview) took place in this language, there is no doubt that he would have had the resources to express himself using lexical items and syntactic structures that fall into the category of standard English. Yet, here he opts for translanguaging as evidenced by the fluid moves between different sets of both linguistic and non-verbal resources. This choice can be explained in several ways. Although the formal part of the class is over and there are thus no expectations of Patrick to talk in French, it seems reasonable to infer that he wishes to continue with his language training. At the moment of the recording, his resources do not (yet) permit him to formulate his thoughts in 'pure' French, so he draws upon additional resources entrenched in his mind. By introducing some words (lines 2 and 5), however, he successfully leads Marianne to respond to him in French, offering a list of useful expressions (lines 9, 10 and 12) that Patrick could apply to let his interlocutors know that he does not understand what is being said. The smooth course of the interaction suggests that translanguaging practices do not disrupt the flow of communication: none of the research participants marks them as nonstandard or deficient usages. Another explanation for this interactional strategy is 
The Version of Record of this manuscript has been published and is available in LANGUAGE AND INTERCULTURAL COMMUNICATION, 2017

$\mathrm{http} / / / w w w . t a n d f o n l i n e . c o m / d o i / f u l l / 10.1080 / 14708477.2017 .1368149$

to see Patrick's choice to employ whatever resources are at his disposal as an expression of his emerging identity as a multilingual language user. As stated earlier, Luxembourgers are claimed to excel at moving freely between languages. For Patrick, who is a newcomer in Luxembourg, similar interactional mechanisms thus seem legitimate. According to his words, he has repeatedly observed them in real-life language use. They might even appear desirable in order to approximate what he perceives to be the norm of communication in the Grand Duchy. Hence, translanguaging not only draws on but also transforms learners' communicative repertoires.

This explanation is in line with the patterns that were repeatedly observed in the written messages Patrick ( $\mathrm{Pa}$ ) exchanged with the researcher $(\mathrm{Re})$ through a messaging application to agree on the dates and activities for ethnographic observation:

Example 1: 'L'allemagne'

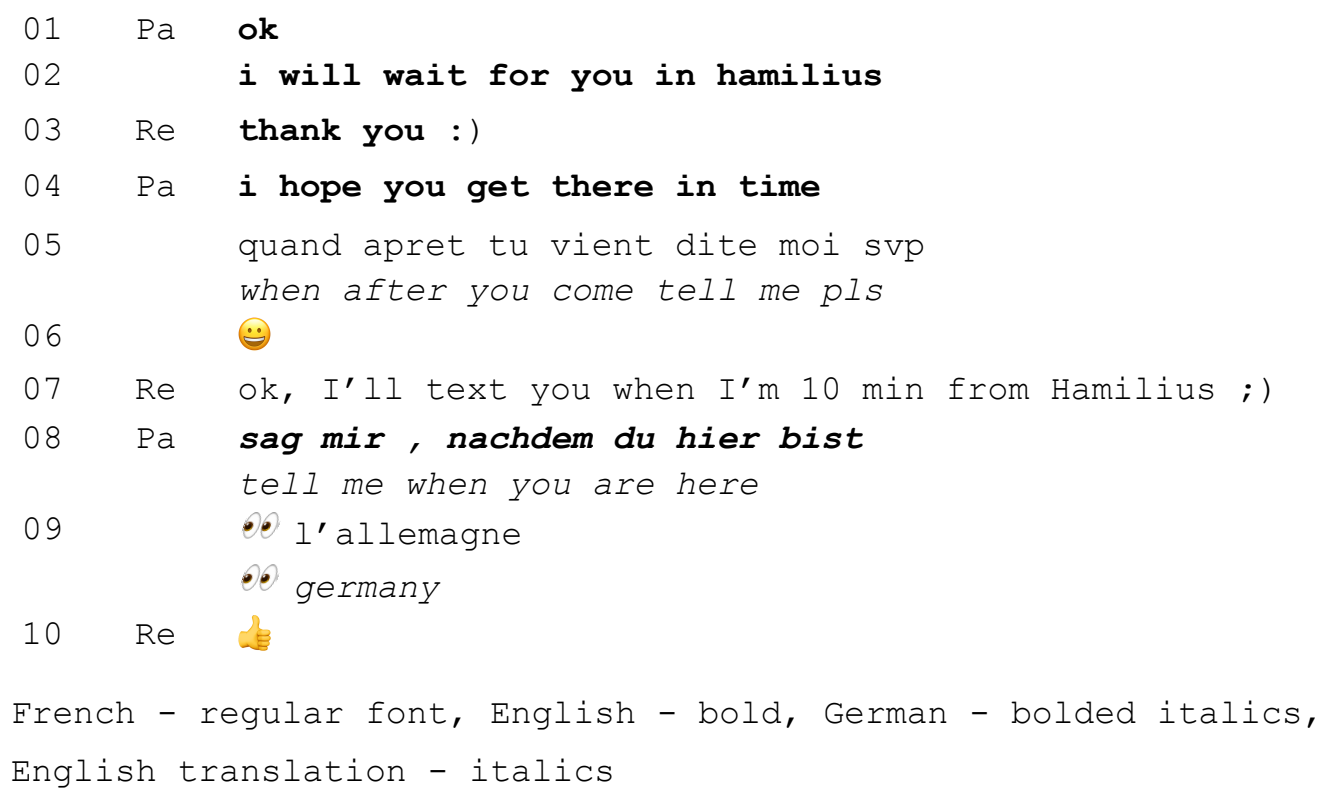

In this brief written interaction, Patrick follows similar translanguaging practices (lines 4, 5 and 8) as outlined above. The exchange took place a few weeks after he had enrolled in a German course for beginners and he was already incorporating some of the newly accumulated resources into his language production (sag mir, nachdem du hier bist). Given the structure and complexity of the phrase, Patrick most likely used machine translation to formulate his thoughts. Nevertheless, the wording of the message already shows a positive attitude and a wish to include German into his communicative repertoire. This is further reinforced in line 9, where he points out that he is now messaging in German as well. As shown here, the languages of the receiving society form an integral part of the learner's everyday experiences and are used for functional purposes from the first day onward. Patrick's 
The Version of Record of this manuscript has been published and is available in LANGUAGE AND INTERCULTURAL COMMUNICATION, 2017

http://www.tandfonline.com/doi/full/10.1080/14708477.2017.1368149

deployment of multilingual communication practices is aligned with the initial language learning goals he set for himself:

Every language if you just learn twenty percent I think you can survive, not really to realize the whole language, just a little bit, I think it's enough.

His approach, despite being explained in terms of percentages of knowledge, resembles the ideas of resourcefulness and repertoire-building put forward by Canagarajah and Wurr (2011). As it will be demonstrated later, he and some other members of the class not only deploy resources that are labelled as belonging to separate languages, but they actively draw on the lexical and structural features these languages share.

Returning now to the analysis of the audio-recorded interaction, the subsequent part of the exchange between Patrick and Marianne shows question-answer turns on how to indicate negation in French:

Extract 4: 'Pas compris'

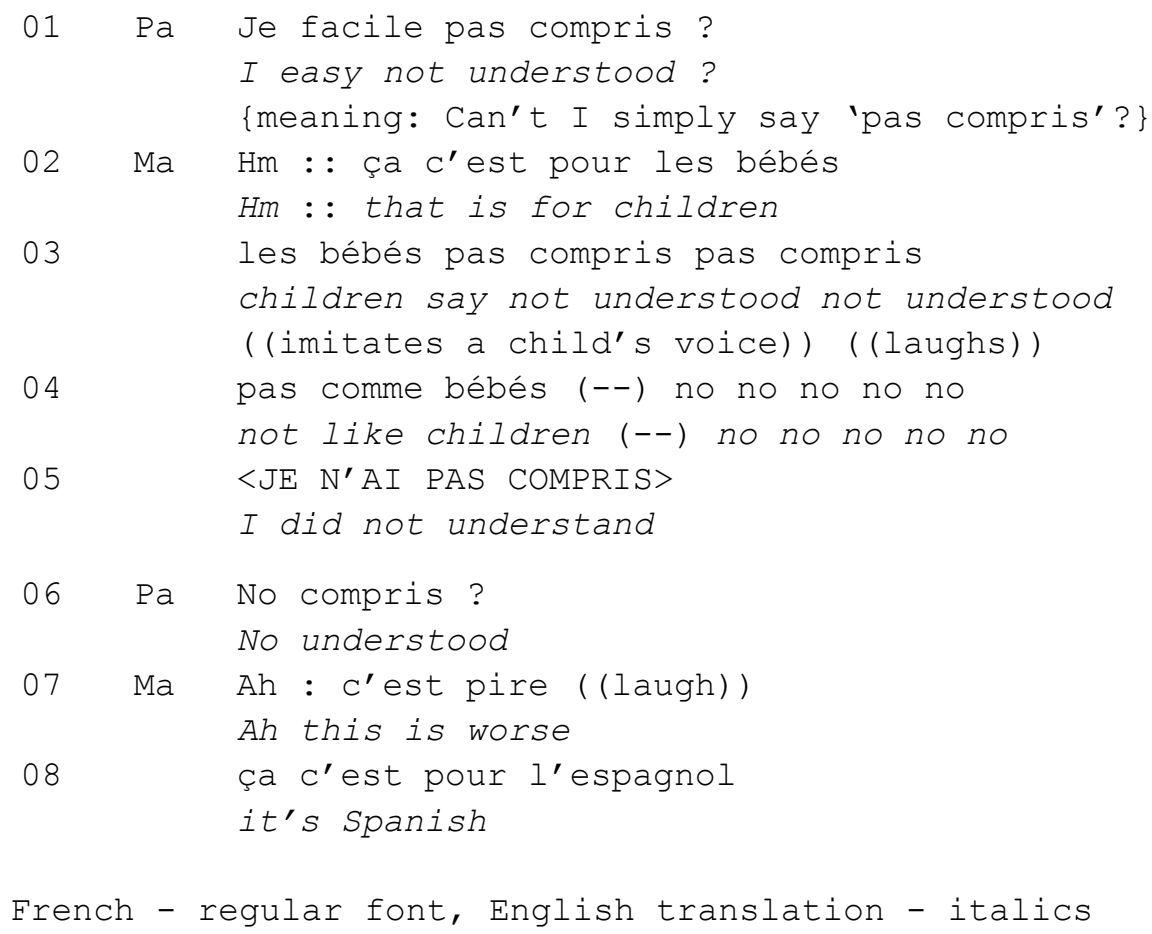

After having been given examples for how to explain to the refugee home's security guard that he does not understand him (je ne comprends pas, je n'ai pas compris), Patrick puts forward different propositions he assumes convey the very same meaning as Marianne's suggestions: pas compris (line 1), no compris (line 6). His propositions are considered 'incorrect' according to established conventions, as pointed out by Marianne when she ascribes 'pas compris' to the speech of infants and indexes 'no compris' as belonging to the Spanish language. It is noticeable that Marianne's turns here are characterised by expressive gesturing and language 
The Version of Record of this manuscript has been published and is available in LANGUAGE AND INTERCULTURAL COMMUNICATION, 2017

$\mathrm{http} / / / w w w . t a n d f o n l i n e . c o m / d o i / f u l l / 10.1080 / 14708477.2017 .1368149$

use (lines 3, 4 and 7) as well as a slower pace of delivery and marked stress (line 5). These salient features can be interpreted as Marianne's attempt to adjust to Patrick reducing the communicative difference between them. At this point, Patrick has a rather limited set of resources in French, but he is actively using his newly acquired knowledge to achieve his communicative aim. It is worth noting that native speakers of French would probably consider most of the utterances that Patrick, Ram or Mannan produce as 'incorrect' [10]. Although the research participants are aware of this fact, they still feel empowered to employ these resources. This suggests that their uses of language are not perceived as deficient by the class.

It was not uncommon for Patrick to engage in exchanges similar to Extract 4. During both the classes and the interview, he showed strong metalinguistic awareness and reflective thinking about learning. For instance, when describing the patterns of classroom interaction, he pointed out that Marianne was his main source of linguistic input, and he commented on how the deployment of different language resources helped him to make himself understood:

I depend on madam Marianne, she speaks with me, I just listen to her, listen to her, and I ask her in English what is the meaning of this, what is the meaning of that? Tell me this, this, this [...] I can speak English and French about ten percent, it's not that much but I can communicate at least...

The typological proximity of the languages spoken in Luxembourg has been a recurring topic in his discourse as well. In Patrick's view, the common structural and functional properties these languages share will to a large extent facilitate his language learning process. This is well illustrated by the following quote:

For the languages here I've found out that German, French and English are near to each other, if you learn English you can learn French and if you learn English you can also learn German. Because lot of things you find in the French language you'll find in each [...] I've found lot of things that I could not find in another country, they speak Portuguese here, also Portuguese is near to French, a lot, it's really connected. You see maybe the languages develop because of the people who speak too many languages.

Similar reflections are present in Mannan's and Ram's accounts of the language learning challenges they are facing in Luxembourg's multilingual environment. An example of how the learners strive to build on the typological proximity of the languages in their repertoires is shown in Extract 6.

After closely following Marianne and Patrick's exchange, Ram (Ra) intervenes in the conversation suggesting an alternative way of responding to the guard in question.

Extract 5: 'Pouvez-vous parler plus doucement ?' 
The Version of Record of this manuscript has been published and is available in LANGUAGE AND INTERCULTURAL COMMUNICATION, 2017

http://www.tandfonline.com/doi/full/10.1080/14708477.2017.1368149

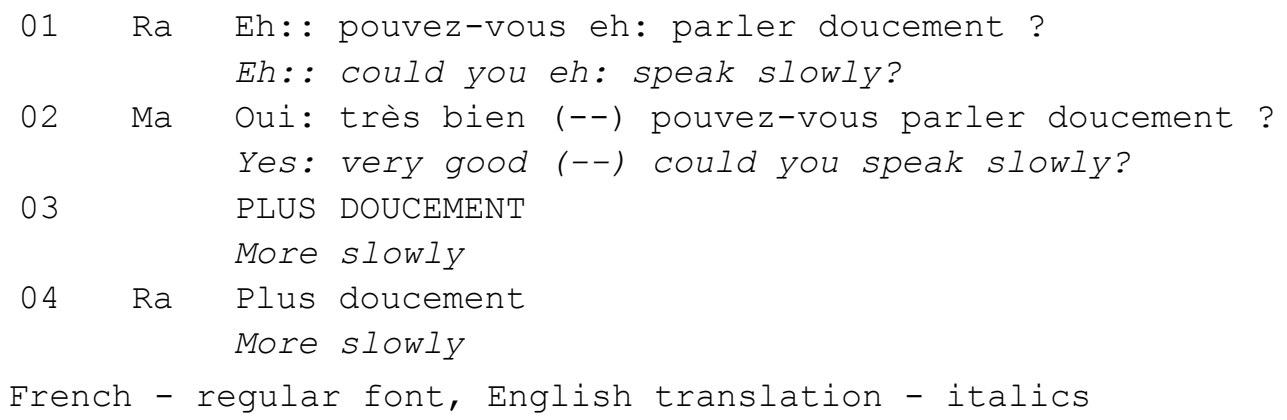

The expression he uses, pouvez-vous parler (plus) doucement, is a phrase the group learned a few sessions prior to the class when the recording was made. The phrase was most likely automatised; however, the fact that Ram's proposition is pertinent to the discussion suggests that he already acquired the language resources, allowing him to follow the conversation that took place between Marianne and Patrick before. It is clear evidence of his learning process. Similar circumstances are best described as simplified receptive multilingualism. Once Ram formulates his thoughts spontaneously, he switches back to Arabic, as shown in the next extract. Here Ram ( $\mathrm{Ra})$, Patrick ( $\mathrm{Pa}$ ) and Marianne (Ma) start co-constructing the phrase 'Could you please repeat it again?', which is the logical continuation of the imagined conversation with the security guard.

\section{Extract 6: 'Por favor'}

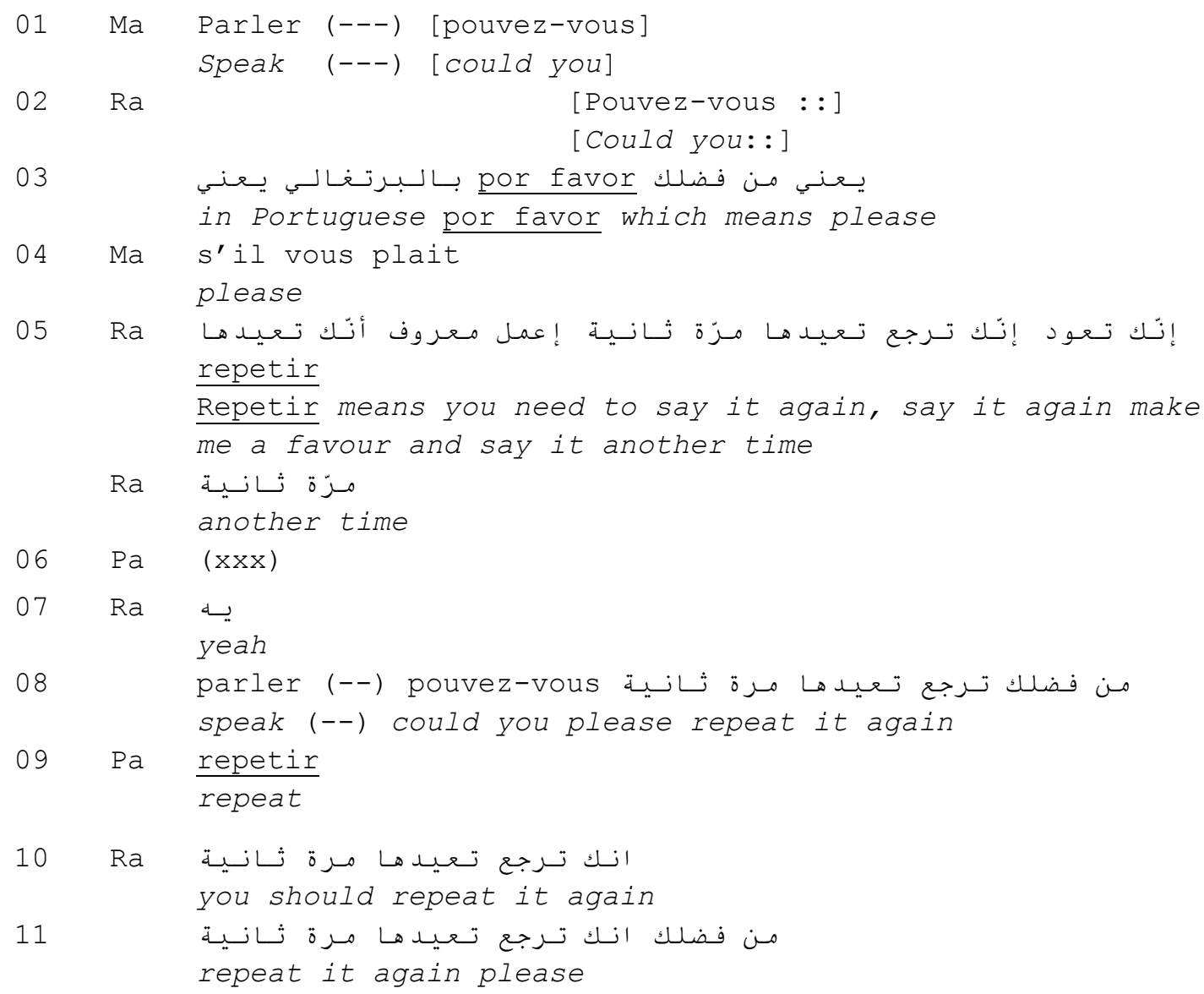


The Version of Record of this manuscript has been published and is available in LANGUAGE AND

INTERCULTURAL COMMUNICATION, 2017

http://www.tandfonline.com/doi/full/10.1080/14708477.2017.1368149

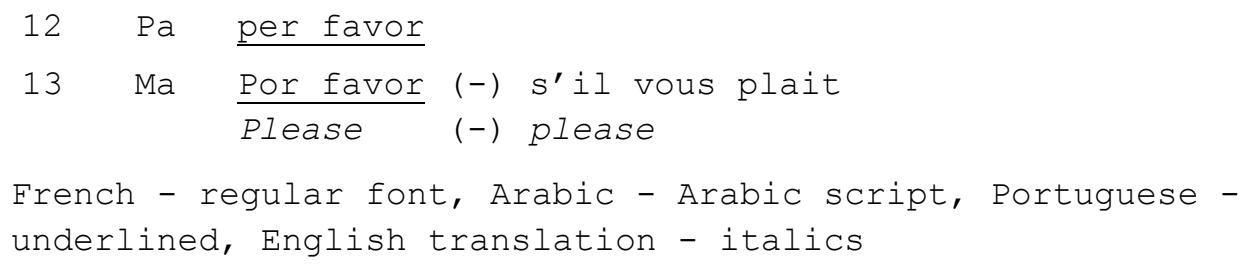

As shown in line 2, Ram begins his sentence with pouvez-vous, copying the structure of the question he learned during the previous sessions (Pouvez-vous parler plus doucement ?). When he hits an impasse and his resources do not allow him to continue (lines 3 and 8), he switches fluidly to Arabic to explain the words he is searching for. What is compelling about this extract is how Ram draws on his knowledge of Portuguese. First, he defines in Arabic the meaning of por favor (line 3), the Portuguese equivalent of 'please'. Presumably, he expects the French expression to be of the same Latin origin. Although his assumption is not correct, the introduction of Portuguese language resources facilitates the meaning-making process as they enable Marianne to provide an immediate translation (line 4): s'il vous plait. Ram introduces another Portuguese-sounding word, repetir (line 5), which is reasonably close in form and pronunciation to its French equivalent: 'répéter'. Patrick picks up both words (lines 9 and 12), despite the fact that Portuguese does not form part of his communicative repertoire. When he returns to the concept of por favor, pronounced as/per favor/, Marianne realises that her previous translation went unnoticed and repeats it, this time more explicitly (line 13). The conversation continues in a similar fashion until the group formulates the complete phrase. As we have seen, interactants occasionally use language resources that do not form part of their interlocutors' active repertoire. This, however, does not necessarily obstruct or impede the flow of the exchange; quite to the contrary, mutual understanding is achieved after few turns. As a result, both Extracts 5 and 6 document reduced forms of what has been described as receptive multilingualism.

\section{Discussion}

While recognising the limitations of this study, we believe to have provided sufficient arguments to maintain that the introduction of additional languages to the classroom not only transformed the interactional mechanisms, creating a more participatory and empowering environment, but also facilitated the accomplishment of learning tasks. Permitting the learners to use their first language(s)/other languages from their repertoire enabled them to verify their understanding, organise their ideas and choose more precise phrasings to explain their thoughts to the teachers and class. Thus, informal translations became a vehicle for learning, as evidenced by the many instances of learners drawing on each other's knowledge. Similarly, the article provided a nuanced view of how receptive multilingualism and translanguaging 
The Version of Record of this manuscript has been published and is available in LANGUAGE AND INTERCULTURAL COMMUNICATION, 2017

http://www.tandfonline.com/doi/full/10.1080/14708477.2017.1368149

were deployed to enhance mutual understanding. For outsiders, the way interlocutors

selected and combined different resources might seem chaotic, but it was the very thing that allowed some learners to get involved in the classroom exchanges in the first place. The fact that these multilingual interactions were perceived as legitimate uses of language shows a shift away from a deficit model of learners and learning.

The group seemed to embrace the affordances of multilingual classroom practices with relative ease. This might be explained to some extent by the language situation learners and teachers experience on a daily basis: the use of multiple languages within a single speech event is rather common in Luxembourg. In our view, this familiarity with multilingual modes of communication translated into classroom practice to a certain extent. Nonetheless, it was still surprising how often teachers and learners drew upon elements from languages they had no extensive competence in. In this sense, the introduction of multiple languages created a learning space that helped the group to see the local languages as new functional resources in their growing repertoires. This insight is of special importance in contexts of forced migration, where learners need to become users of the languages they are learning from the first day onward. Hence, this contribution can be seen as a first step towards defining a repertoirebuilding approach that would equip refugees with adequate resources to successfully navigate local life in societies where multiple languages are at use.

To conclude, the communicative exchanges documented in this article allowed us to make visible the diverse resources that teachers and learners brought to the classroom. The examples shown here demonstrated how multilingual practices such as translation, translanguaging and receptive multilingualism supported the meaning-making process, even in those cases where the interactants had very few resources in each other's languages. In numerous instances, these practices provided an excellent starting point for language learning, be it in the form of metalinguistic reflection, clarification of exact meanings, utilisation of newly acquired skills or learners making their voices heard. While the findings need to be interpreted in light of the small scale of the study, they do shed light on some of the opportunities that emerge with a multilingual orientation. Further research is needed to investigate to what extent the theorisation presented here holds true in other contexts and more advanced levels. Another promising research avenue could be to explore whether and how multilingual pedagogies come to be accepted and legitimated across a variety of educational settings. There is growing support for approaches that consider language as a resource and promote the use of communicative repertoires: a useful step forward would be to examine the possible implications for language testing and assessment, especially in contexts of forced migration. 
The Version of Record of this manuscript has been published and is available in LANGUAGE AND

INTERCULTURAL COMMUNICATION, 2017

http://www.tandfonline.com/doi/full/10.1080/14708477.2017.1368149

\section{Endnotes}

1. Luxembourg's language situation is not described in detail here. For a comprehensive overview, see Horner and Weber (2008).

2. 'Researcher' here refers to the author of the article.

3. CEFR level A1 is the lowest level of generative language use: the point at which learners can interact in a simple way, ask and answer simple questions about themselves, and respond to simple statements in areas of immediate need.

4. The centre's teachers, Marie and Marianne, expressed a wish to have their contributions recognised with their real names. The asylum applicants opted for pseudonymity and we agreed on a name with each of them during the consent process.

5. At the beginning of the course, 13 learners were enrolled, but class attendance was rather irregular.

The asylum seekers had frequent appointments with lawyers, social workers and authorities, which prevented them from attending the sessions as often as they would have wished to. The irregular attendance had major consequences for the selection of research participants: the researcher managed to establish trust with and recruit only those learners who could attend the classes with higher regularity.

6. English was the main language of communication with most of the participants: Marianne is an English native speaker; Marie, Patrick and Mannan felt comfortable expressing their views relying mostly on English language resources. Although questions were asked in English, Marie was offered the option to respond in French, and Mannan often drew on the help of his cousin, who was also present during the interview: he explained the researcher's questions in Arabic where necessary and translated for Mannan when he had difficulties in expressing himself in English. Ram was interviewed in Arabic with the help of a research assistant, Yacine, who assumed the role of English-Arabic interpreter. As to the mode, consecutive interpreting was agreed upon with the interview participants. According to Yacine, there were only a few instances where dialectal differences became salient; in these cases, mutual understanding was achieved through paraphrasing in Arabic. Translation software and multimodal aids (pictures, maps, newspaper articles and videos) were used on occasion as well, in particular when the research participants found it hard to express their ideas using verbal resources only. An important source of data was informal interviews and brief discussions with research participants. These occurred mostly in English and French. The quotations included in the article were all formulated in English by the research participants and/or the person interpreting. Upon the participants' request, filler words, false starts and irregular grammatical features have been removed.

7. In the process of transcribing, we encountered difficulties in deciding how to label certain features. For instance, in Extract 3 line 6, 'okay' could have been marked either as English or French. Since the rest of the utterance is analysed as French, we decided to leave the word in regular font and 
The Version of Record of this manuscript has been published and is available in LANGUAGE AND

INTERCULTURAL COMMUNICATION, 2017

http://www.tandfonline.com/doi/full/10.1080/14708477.2017.1368149

treat it as an item belonging to the French lexicon. Thus, not-switching is the default option in the representation of the data set. The same logic has been followed in similar cases. In Extract 6 line 5, the word 'repetir' also creates some confusion: one might argue that the research participant had in mind the French verb répéter' or even the English equivalent 'repeat'. The pronunciation was ambiguous; hence, the decision to categorise the item as a Portuguese-sounding word was based on contextual clues. Some items were difficult to attribute to any language. In Extract 3 line 5, Patrick pronounces some words that resemble the French personal pronoun ' $t u$ ', and we analysed them as such. Nevertheless, the sounds he pronounced could have belonged to a different language system as well. 'Per favor' (Extract 6 line 12) is a Catalan expression; however, bearing in mind the language biographies of the research participants, it was labelled as a Portuguese item pronounced with an altered pronunciation.

8. The Arabic segments of the excerpts included in this article were transcribed and translated into English by Malika. In her view, the dialects spoken by the two research participants (Patrick and Ram), whose voices are heard in the recording, are very close to her Jordanian dialect. The transcription was done keeping in mind the dialectal features of the variety spoken by these research participants. The transcripts were also proofread for correctness by the other Arabicspeaking project collaborator.

9. As a result of the presence of learners from Afghanistan, Kosovo and Montenegro, other language resources were also introduced to the classroom, though very sporadically. No other member of the group spoke or understood the (first) languages of these learners; so the main medium of communication between them and the rest of the class was mostly English.

10. The extracts contain numerous words and syntactic constructs that would traditionally be categorised as incorrect or as belonging to a 'broken' variety. The English translations are approximations aimed at representing the same structural features as the original utterances.

\section{Acknowledgements}

The author thanks the teachers and learners whose participation made this study possible.

The author gratefully acknowledges the assistance and support of Sabine Ehrhart, Malika Shatnawi, Natalia Bîlici, Yacine Chemssi, Julia de Bres, Dorte Lønsmann and Markus Rheindorf.

\section{Disclosure statement}

No potential conflict of interest was reported by the author. 
The Version of Record of this manuscript has been published and is available in LANGUAGE AND

INTERCULTURAL COMMUNICATION, 2017

http://www.tandfonline.com/doi/full/10.1080/14708477.2017.1368149

\section{References}

Bailey, B. (2007). Heteroglossia and Boundaries. In M. Heller (ed.), Bilingualism: a social approach (pp. 257-276), Basingstoke: Palgrave Macmillan.

Blommaert, J. \& Backus, A. (2011). Repertoires revisited: 'Knowing language' in superdiversity, Working Papers in Urban Language \& Literacies, 67, 1-26.

http://www.kcl.ac.uk/sspp/departments/education/research/ResearchCentres/ldc/publications/workingpapers/the-papers/67.pdf

Byram, M. \& Hu, A. (eds.) (2013). Routledge Encyclopedia of Language Teaching and Learning. Abingdon: Routledge.

Calis, E. \& Dikilitas, K. (2012). The Use of Translation in EFL Classes as L2 Learning Practice, Procedia - Social and Behavioral Sciences, 46, 5079-5084. doi: 10.1016/j.sbspro.2012.06.389

Canagarajah, A. S. \& Wurr, A. J. (2011). Multilingual Communication and Language Acquisition: New Research Directions, The Reading Matrix, 11 (1), 1-15.

Carreres, A. (2006). Strange bedfellows: Translation and language teaching. The teaching of translation into $L 2$ in modern languages degrees: Uses and limitations. In $6^{\text {th }}$ Symposium on Translation, Terminology and Interpretation in Cuba and CanadaDecember 2006. http://www.cttic.org/ACTI/2006/papers/Carreres.pdf

Copland, F. \& Creese, A. (2015). Linguistic Ethnography. Collecting, Analysing and Presenting Data. London: SAGE Publications.

Cook, V. (2007). The goals of ELT: Reproducing native-speakers or promoting multicompetence among second language users? In J. Cummins and C. Davison (eds.), International handbook of English language education 1 (pp. 237-248), Norwell: Springer

Creese, A. \& Blackledge, A. (2010). Translanguaging in the Bilingual Classroom. A Pedagogy for Learning and Teaching, The Modern Language Journal, 94 (1), 103-115. doi: 10.1111/j.1540-4781.2009.00986.x

Cummins, J. (2007). Rethinking monolingual instructional strategies in multilingual classrooms; Canadian Journal of Applied Linguistics, 10 (2), 221-240.

de Bres, J. (2014). Competing language ideologies about societal multilingualism among crossborder workers in Luxembourg, International Journal of the Sociology of Language, 227, 119-137. doi: 10.1515/ijsl-2013-0091

Franziskus, A. \& Gilles, P. (2012). 'Et le präis direct etikett?' Non-overlapping repertoires in workplace communication in Luxembourg, Sociolinguistica, 26 (1), 58-71. doi: 10.1515/soci.2012.26.1.58 
The Version of Record of this manuscript has been published and is available in LANGUAGE AND

INTERCULTURAL COMMUNICATION, 2017

http://www.tandfonline.com/doi/full/10.1080/14708477.2017.1368149

García, O. (2009). Bilingual education in the 21st century: A global perspective. Oxford: WileyBlackwell.

García, O. \& Li Wei (2014). Translanguaging: Language, Bilingualism and Education, Basingstoke: Palgrave.

Gogolin, I. (1997). The "monolingual habitus" as the common feature in teaching in the language of the majority in different countries, Per Linguam, 13 (2), 38-49. doi: $10.5785 / 13-2-187$

Gumperz, J. (2003). Interactional sociolinguistics. A personal perspective. In: D. Schiffrin, D. Tannen \& H. Hamilton (eds.), The Handbook of Discourse Analysis (pp. 215-228), Malden: Blackwell.

Jessner, U. (2006). Linguistic awareness in multilinguals: English as third language. Edinburgh: Edinburgh University Press.

Horner, K. (2015). Language regimes and acts of citizenship in multilingual Luxembourg. Journal of Language and Politics, 14 (3), 359-381.

Horner, K. \& Weber, J. J. (2008). The language situation in Luxembourg. Current Issues in Language Planning, 9 (1), 69-128.

Jørgensen, N. (2008). Polylingual Languaging Around and Among Children and Adolescents, International Journal of Multilingualism, 5 (3), 161-176. doi:

$10.1080 / 14790710802387562$

Jørgensen, N., Karrebæk, M. S., Madsen, L. M. \& Møller, J. S. (2011). Polylanguaging in Superdiversity, Diversities, 13 (2), 22-37.

Le Nevez, A., Hélot, Ch. \& Ehrhart, S. (2010). Negotiating plurilingualism in the classroom. In A. Le Nevez, Ch. Hélot \& S. Ehrhart (eds.), Plurilinguisme et Formation des Enseignants: Une approche critique (pp. 5-21). Bern: Peter Lang.

Lüdi, G. (2006). Multilingual repertoires and the consequences for linguistic theory. In K. Bührig \& J. D ten Thije (eds.), Beyond Misunderstanding: Linguistic analysis of intercultural communication (pp. 11-42). John Benjamins Publishing Company. DOI: 10.1075/pbns.144.03lud

Lüdi, G. \& Py, B. (2009). To be or not to be ... a plurilingual speaker. International Journal of Multilingualism, 6 (2), 154-167. doi:10.1080/14790710902846715

Otsuji, E. \& Pennycook, A. (2010). Metrolingualism: fixity, fluidity and language in flux. International Journal of Multilingualism, 7 (3), 240-254. doi: $10.1080 / 14790710903414331$ 
The Version of Record of this manuscript has been published and is available in LANGUAGE AND

INTERCULTURAL COMMUNICATION, 2017

$\mathrm{http} / /$ www.tandfonline.com/doi/full/10.1080/14708477.2017.1368149

Rehbein, J., Ten Thije, J. D. \& Verschik, A. (2011). Lingua receptiva (LaRa) - remarks on the quintessence of receptive multilingualism, International Journal of Bilingualism, 16 (3), 248-264. doi: 10.1177/1367006911426466

Rymes, B. (2014). Communicating Beyond Language. Everyday Encounters with Diversity, London: Routledge.

Patton, M.Q. (2002). Qualitative Research and Evaluation Methods. Thousand Oaks: SAGE.

Statec (2016a). Le Luxembourg en chiffres. Luxembourg: Statec.

http://www.statistiques.public.lu/catalogue-publications/luxembourg-en-

chiffres/2016/luxembourg-figures.pdf

Statec (2016b). Population par nationalités détaillées 2011-2016. Luxembourg: Statec.

http://www.statistiques.public.lu/stat/TableViewer/tableView.aspx?Reportld=12859\& IF Language $=$ fra\&MainTheme $=2$

Van Avermaet, P. (2009). Fortress Europe? Language policy regimes for immigration and citizenship. In C. Mar-Molinero \& P. Stevenson (eds.), Language Ideologies, Policies and Practice: Language and the Future of Europe (pp. 15-43). Basingstoke: Palgrave Macmillan.

Vetter, E. (2011). Exploiting receptive multilingualism in institutional language learning: The case of Italian in the Austrian secondary school system, International Journal of Bilingualism, 16 (3), 348-365. doi: 10.1177/1367006911426385 
The Version of Record of this manuscript has been published and is available in LANGUAGE AND INTERCULTURAL COMMUNICATION, 2017

http://www.tandfonline.com/doi/full/10.1080/14708477.2017.1368149

\section{APPENDIX}

\section{Transcription Conventions}

\begin{tabular}{|c|c|}
\hline$(-) \quad(--) \quad(---)$ & silences up to 1 second \\
\hline$(1.0)$ & silences in seconds \\
\hline$[\quad]$ & overlapping speech \\
\hline$(($ laugh $))$ & paralinguistic features and situational description \\
\hline (hello) & stretch of uncertain transcription \\
\hline$(x \times x)$ & stretches of inaudible/unclear talk \\
\hline ? & rising intonation or question \\
\hline yes. & falling final intonation \\
\hline oui: : : & one or more colons indicate lengthening of the \\
\hline & preceding sound; each additional colon represents a \\
\hline & lengthening of one beat \\
\hline NO & large capitals indicate loud volume \\
\hline$[\ldots]$ & ellipsis \\
\hline$<$ por favor $>$ & $\langle\ldots\rangle$ indicates slowed down delivery relative to the \\
\hline & surrounding talk \\
\hline
\end{tabular}

